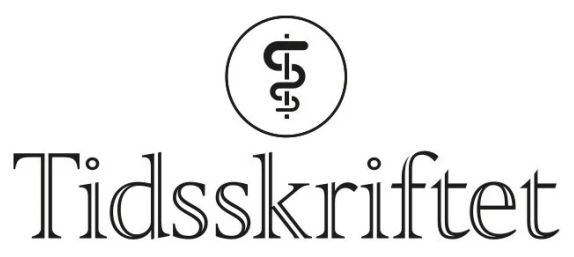

DEN NORSKE LEGEFORENING

\title{
Hørselskontroll er dårlig støyvern
}

\author{
KRONIKK
}

\section{ERLEND HASSEL}

erli123@hotmail.com

Erlend Hassel er ph.d. og spesialist i arbeidsmedisin. Han er ansatt i 50 \% stilling som overlege ved Arbeidsmedisinsk avdeling, St. Olavs hospital, og har en 50 \% stilling som bedriftslege ved Forsvarets bedriftshelsetjeneste Midt-Norge og Nordland.

Forfatteren har fylt ut ICMJE-skjemaet og oppgir ingen interessekonflikter.

\section{Arbeidsgivere i Norge er pålagt å sørge for at støyeksponerte arbeidstakere gjennomgår hørselsundersøkelser for å avdekke utvikling av støyskader. Evidensgrunnlaget for praksisen er i beste fall tynt.}

Forskrift om utførelse av arbeid pålegger arbeidsgivere å sørge for at arbeidstakere som eksponeres for åtte timers gjennomsnittlig støy over $80 \mathrm{~dB}(\mathrm{~A})$ eller impulslyd over $130 \mathrm{~dB}$ (C) gjennomgår helseundersøkelse med hørselskontroll. Forskriften angir videre at helseundersøkelsen skal kunne påvise enhver negativ helseeffekt forårsaket av støy og gi grunnlag for forebyggende tiltak i virksomheten (1). I Arbeidstilsynets kommentarer til forskriften står det at hørselskontrollen gir grunnlag for individuell informasjon og veiledning, slik at det kan settes i gang tiltak før det oppstår hørselsskade av betydning (므). Målet med disse pålagte helseundersøkelsene er altså todelt:1) Gi arbeidsgiver et beslutningsgrunnlag for å vurdere tiltak i virksomheten rettet mot å redusere negative helseeffekter forårsaket av støy på gruppenivå, og 2) Påvise helseskade forårsaket av støyeksponering på et tidlig tidspunkt, slik at man gjennom individuelle tiltak og tilrettelegginger kan redusere risiko for videre utvikling av helseskaden. Dersom helseundersøkelser og hørselskontroll virkelig kan bidra til å oppnå denne målsettingen, er dette selvfølgelig svært positivt. Problemet er at det ikke foreligger vitenskapelige bevis som dokumenterer eller sannsynliggjør at slik helsescreening av støyeksponerte er effektivt. Tiltak for å redusere risikoen for yrkesbetinget hørselstap vil uansett måtte basere seg på kartlegging og risikovurdering av støyeksponering, så verdien av hørselsundersøkelser er uansett begrenset.

\section{Støy og hørselstap}

Hørselsundersøkelser med audiometri har blitt gjennomført i Helseundersøkelsen i NordTrøndelag både i årene 1996-98 (HUNT2) og i 2017-19 (HUNT4). Disse undersøkelsene gir verdifull innsikt i forekomst av hørselstap i befolkningen. Det er gledelig at forekomsten av 
hørselstap har blitt lavere i løpet av disse 20 årene, og at noe av forklaringen synes å være redusert støyeksponering i arbeid (3). Til tross for denne reduksjonen vil de fleste oppleve at hørselen svekkes med økende alder - også de uten støyeksponering på jobb.

\section{"Audiometri kan ikke med tilstrekkelig sikkerhet skille mellom de som har et støyindusert hørselstap og de som har et hørselstap av andre fysiologiske eller patofysiologiske årsaker»}

Arbeidstilsynet anbefaler at hørselstap inndeles i grad 1-3 (der grad 3 er mest alvorlig) basert på høreterskler for ulike frekvenser i taleområdet målt med audiometri (4). Dersom man tar utgangspunkt i denne klassifiseringen og bruker yrkesaktive menn i aldersgruppen 40-49 år som eksempel, finner man i data fra HUNT 4 en prevalens av hørselstap grad 1-3 på hele $62 \%$. Holder man de med støyeksponering i arbeid utenfor, er tilsvarende tall $56 \%$ (5). Om dette er overførbart til resten av befolkningen, taler dette for at så mange som $6 \%$ av menn i denne aldersgruppen i Norge har et hørselstap som skyldes støyeksponering på jobb. Dette eksempelet illustrerer både at prevalensen av hørselstap er svært høy i den generelle befolkningen og at støy i arbeidslivet fortsatt er et betydelig problem på samfunnsnivå med stor innvirkning på folkehelsen.

\section{Den salige helseundersøkelsen}

Rentoneaudiometri er den mest aktuelle helseundersøkelsen hos støyeksponerte. Dette er en enkel og ikke-invasiv undersøkelse som rimelig nøyaktig og reproduserbart kan påvise hørselstap. Hørselen er mest sårbar for støyeksponering i frekvensområdet 3-6 kHz. Hos de med støyindusert hørselstap vil man derfor kunne se et «hakk» i hørselskurven i dette området. Man kan gjøre gjentatte undersøkelser, og på den måten følge utvikling av hørselstapet over tid. Støyeksponering kan gi et raskere hørselstap enn det man vanligvis ser ved aldersrelatert hørselstap. Hvis støyindusert hørselstap påvises tidlig, kan man sette inn målrettede tiltak for å hindrevidere støyeksponering slik at utviklingen av hørselstapet stanses.

\section{«Den eneste effektive strategien for å redusere støyindusert hørselstap er å sette inn tiltak for å redusere eksponeringen for støy»}

Dessverre er det et stort problem med denne strategien: Audiometri kan ikke med tilstrekkelig sikkerhet skille mellom de som har et støyindusert hørselstap og de som har et hørselstap av andre fysiologiske eller patofysiologiske årsaker. Ingen supplerende undersøkelser kan sikkert identifisere de med støyindusert hørselstap. Gitt den høye forekomsten av hørselstap også hos dem som ikke er støyeksponerte, er dette svært problematisk. «Hakket» i audiometri-kurven er vanlig også hos dem som ikke eksponeres for støy i arbeidssammenheng: I HUNT2 ble slike hakk funnet hos 6o-70 \% av mennene med høyest støyeksponering, mens 50-6o \% av menn uten selvrapportert yrkeseksponering for støy også hadde slike hakk (므). For kvinner var forskjellen mellom støyeksponerte og ikke støyeksponerte enda mindre (므). Permanent terskelheving, det vil si en dokumentert økning i høreterskelen på $15 \mathrm{~dB}$ eller mer i frekvensområdet 3-6 kHz innenfor 3 år eller mindre, anbefales av Arbeidstilsynet som kriterium ved diagnostisering av støyskade (4). Imidlertid presenteres det ikke data som angir hvor sensitivt og spesifikt dette kriteriet er. Altså vet man ikke hvor stor andel av de som har en begynnende støyskade som identifiseres eller hvor mange av de som ikke er støyeksponerte som likevel får positivt utslag på dette kriteriet. Fortolkning av resultater fra audiometri er derfor nesten umulig, ikke minst når man skal vurdere resultater på gruppenivå for å gi arbeidsgiver et beslutningsgrunnlag for tiltak mot støyindusert hørselstap.

\section{Forebyggende tiltak}


Sammenhengen mellom støyeksponering og hørselsskade er velbeskrevet. Dersom man vet hvor stor støyeksponeringen er, kan man på gruppenivå forutsi hvor mye hørselen vil svekkes med tiden. Den eneste effektive strategien for å redusere støyindusert hørselstap er å sette inn tiltak for å redusere eksponeringen for støy. Slike tiltak må baseres på kartlegging av støyeksponering og kan gjennomføres uavhengig av resultater fra audiometri. Kartleggingen bør inkludere en beskrivelse av arbeidsoppgaver, tidsbruk, støykilder og allerede iverksatte tiltak for å redusere støynivået på arbeidsplassen. Dersom det er mistanke om at støyeksponeringen kan være høyere enn grensene i forskriften utføres støymåling etter standardisert prosedyre (7.). Ikke bare gir slik kartlegging et godt grunnlag for å vurdere risiko for yrkesbetinget hørselsskade, men man vil også identifisere hvilke støykilder og arbeidsprosesser som bidrar mest til den totale belastningen. Dette gir arbeidsgiver et grunnlag for å sette inn tiltak der hvor man kan forvente størst effekt. Etter gjennomførte tiltak foretas ny kartlegging for å verifisere at ønsket effekt er oppnådd. Det såkalte tiltakshierarkiet (hierarchy of controls) er en veletablert og mye brukt modell for prioritering av tiltak for å redusere eksponering i arbeidslivet. De mest effektive tiltakene er plassert øverst, med gradvis mindre effektive tiltak lenger ned. Det mest effektive er å eliminere kilden til støyen, eller fjerne arbeidstakerne fra det området støyen er. Dernest kan man endre eller bytte ut prosesser eller utstyr, slik at de genererer mindre støy. Neste trinn er tekniske tiltak, slik som innkapsling av støykilden eller montering av støyabsorbenter på overflater. Alternativt kan arbeidstakerne innkapsles (i et kontrollrom eller lignende), men tekniske støyreduserende tiltak har som regel best effekt dersom de settes inn nærmest mulig støykilden. Det nest nederste trinnet er organisatoriske tiltak, som opplæring om støy, potensielle helseeffekter og beskyttelsestiltak. Rutiner for arbeidsprosesser bør optimaliseres, slik at minst mulig støy genereres. Før støyende arbeidsoppgaver igangsettes, bør alle arbeidstakere i det aktuelle området varsles. Rulleringsordninger på støyende arbeidsoppgaver kan hindre at noen individer får spesielt høye støydoser.

\section{"Totalt sett er det åpenbart at audiometriscreening ikke oppfyller kvalitetskravene som stilles til nasjonale screeningprogram»}

Det nederste trinnet på tiltakshierarkiet, og det minst effektive, er personlig verneutstyr. Dette vil være aktuelt dersom man ikke har kommet i mål med øvrige tiltak. Det finnes mange ulike typer hørselvern, fra enkle propper eller øreklokker, til avanserte systemer med aktiv støydemping og logging av støyeksponering målt ved trommehinnen. Den reelle støydempende effekten av hørselsvern er imidlertid ofte dårligere enn det produsenten oppgir. Dempningseffekten målt under faktisk bruk ligger gjerne under halvparten av de oppgitte verdiene som er målt under ideelle forhold. Samtidig kan variasjonen i oppnådd dempningseffekt mellom ulike brukere være stor (모). Enkelte arbeidstakere kan derfor ha svært liten støydempende effekt av et gitt hørselsvern. I noen tilfeller bør derfor effektiv dempningseffekt måles på individnivå.

\section{Audiometri og nasjonale screeningprogram}

Basert på internasjonalt anerkjente kriterier har Helsedirektoratet laget en liste med kvalitetskriterier som bør være innfridd før innføring av nye nasjonale screeningprogrammer ramme 1$)$ ((9.).

\section{Ramme 1 Helsedirektoratets vurderingskriterier for nye nasjonale screeningprogrammer (9).}

1. Tilstanden skal være et viktig helseproblem. 
2. Tilstandens naturlige forløp skal være tilstrekkelig kjent.

3. Tilstanden skal ha en symptomfri fase som kan detekteres.

4. Det må finnes en sikker, presis og validert test.

5. Kriterier og prosedyrer for videre oppfølging av testpositive må være definert.

6. Testmetoden skal være akseptabel for målgruppen.

7. Det må finnes tiltak eller behandling som gir bedre effekt i tidlig stadium enn ved klinisk diagnostikk.

8. Tiltak/behandling må være etablert og godt dokumentert.

9. Tiltak/behandling skal være akseptable for målgruppen.

10. Screeningprogrammet skal redusere sykdomsspesifikk dødelighet eller sykelighet av tilstanden.

11. Helsegevinstene må være større enn de negative effektene.

12. Personvern og juridiske aspekter må være ivaretatt.

13. Screeningprogrammet skal være akseptabelt fra et etisk perspektiv.

14. Informasjon om deltagelse i screeningprogrammet må være kunnskapsbasert og bidra til informerte valg.

15. Screeningprogrammet skal tilfredsstille kravene til kostnadseffektivitet.

16. Det må foreligge en plan for ledelse, kvalitetssikring og evaluering av programmet.

Selv om systematisk undersøkelse av støyeksponerte arbeidstakere med audiometri formelt sett ikke er underlagt disse kriteriene, er audiometriscreeningen en form for lovpålagt helsescreening på nasjonalt nivå, og mange av de samme vurderingene er derfor likevel gjeldende. Ved gjennomgang av kriteriene ser man at screeningen har tydelige mangler. Selv om testen er trygg og til en viss grad presis, er den ikke tilstrekkelig validert da sensitivitet og spesifisitet for å påvise støyindusert hørselstap ikke er kjent. Etablerte kriterier for testpositivitet mangler, det samme gjør prosedyrer for oppfølging på overordnet nivå. Randomiserte kliniske studier som viser at audiometriscreening reduserer fremtidig hørselstap finnes ikke, og man kan da heller ikke konkludere med at helsegevinsten er større enn de negative effektene. Mangelen på randomiserte studier vanskeliggjør også tilstrekkelig godt informert samtykke, og gjør det umulig å vurdere kostnadseffektivitet. Det foreligger i hovedsak ingen plan for kvalitetssikring eller evaluering av screeningen. Totalt sett er det åpenbart at audiometriscreening ikke oppfyller kvalitetskravene som stilles til nasjonale screeningprogram.

\section{Er det så farlig da?}

Audiometri er heldigvis en relativt ufarlig undersøkelse med få negative konsekvenser for den enkelte. Kanskje vil det for noen være negativt å få beskjed om at de har en sannsynlig støyskade grunnet eksponeringer på jobb, når de egentlig har et hørselstap av naturlige årsaker. Noen vil kanskje omplasseres til annen jobb på feilaktig grunnlag. Hovedvekten av de negative effektene av audiometriscreening vil likevel være på gruppenivå. I følge lovverket skal arbeidsgiver bruke resultater fra audiometriscreening som beslutningsgrunnlag i forhold til tiltak rettet mot å redusere negative helseeffekter av støy. Dette er en unødvendig omvei for å nå målet om å hindre at arbeidstakere får redusert hørsel på grunn av eksponering på jobb. For å få kontroll på risiko må man uansett foreta kartlegging og risikovurdering av støyeksponering, for så å basere tiltak på dette. Når audiometriscreening i tillegg har så betydelige feilkilder, risikerer man at arbeidsgiver får uriktig informasjon om risikoforhold i virksomheten. Dette vil kunne bidra til å dra fokus vekk fra der hvor risikoen er størst og føre til feil prioritering av tiltak. 


\section{LITTERATUR}

1. FOR-2011-12-o6-1357. Forskrift om utførelse av arbeid, bruk av arbeidsutstyr og tilhørende tekniske krav (forskrift om utførelse av arbeid), §14.11. https://lovdata.no/dokument/SF/forskrift/2011-12-o6-1357| Lest 9.3.2021.

2. FOR-2011-12-o6-1357. Forskrift om utførelse av arbeid, bruk av arbeidsutstyr og tilhørende tekniske krav (forskrift om utførelse av arbeid), §14.11.

https://www.arbeidstilsynet.no/globalassets/regelverkspdfer/forskrift-om-utforelse-av-arbeid/ Lest 9.3.2021.

3. Engdahl B, Stigum H, Aarhus L. Explaining better hearing in Norway: a comparison of two cohorts 20 years apart - the HUNT study. BMC Public Health 2021; 21: 242. [PubMed][CrossRef]

4. Arbeidstilsynet. Temaside om hørselskontroll. https://www.arbeidstilsynet.no/hms/roller-i-hmsarbeidet/arbeidsgiver/helsekontroll/horselskontroll/ Lest 9.3.2021.

5. Faktabok om arbeidsmiljø og helse. STAMI-rapport, årgang 22, nr. 4. Oslo: Statens arbeidsmiljøinstitutt, 2021. https://stami.no/content/uploads/2021/o6/Faktabok-omarbeidsmilj\%C3\%B8-og-helse-2021.pdf Lest 6.6.2021.

6. Lie A, Engdahl B, Hoffman HJ et al. Occupational noise exposure, hearing loss, and notched audiograms in the HUNT Nord-Trøndelag hearing loss study, 1996-1998. Laryngoscope 2017; 127:144250. [PubMed][CrossRef]

7. Norsk standard 4815:1. Måling av yrkesmessig eksponering av støy for arbeidstakere. Oslo: Standard Norge, 2006. https://www.standard.no/no/Nettbutikk/produktkatalogen/Produktpresentasjon/? ProductID $=158359$ Lest 9.3.2021.

8. Berger EH. The naked truth about NRRs. Technical monograph EAR-log nr. 20/1993. Indianapolis, IN: Aero company, 1993. https://multimedia.3m.com/mws/media/893196O/earlog-20.pdf Lest 7.4.2021.

9. Nasjonalt screeningprogram mot tarmkreft - status og anbefalinger. Oslo: Helsedirektoratet, 2017. https://www.helsedirektoratet.no/tema/kreft/screeningprogram-for-

kreft/Nasjonalt\%2oscreeningprogram\%2omot\%2otarmkreft.pdf/_/attachment/inline/4do8a95a-302e4607-80a1-

3e44223bfae7:956dga1b63c6af83beb53abf5fa7860216738ac9/Nasjonalt\%2oscreeningprogram\%2omot\%2 otarmkreft.pdf Lest 9.3.2021.

Publisert: 30. august 2021. Tidsskr Nor Legeforen. DOI:10.4045/tidsskr.21.0195

Mottatt 10.3.2021, første revisjon innsendt 7.4.2021, godkjent 28.4.2021.

(C) Tidsskrift for Den norske legeforening 2023. Lastet ned fra tidsskriftet.no 26. april 2023. 